\title{
Synthesis of tetrahydroindazol-4(5H)one and 7-thione from reaction of functionalized cyclic enaminones with hydrazine
}

\author{
El Sayed H. El Ashry ${ }^{1, *}$, Laila F. Awad ${ }^{1}$ and Omayma Kh. Bdeewy ${ }^{2}$ \\ ${ }^{1}$ Chemistry Department, Faculty of Science, Alexandria University Alexandria, Egypt \\ ${ }^{2}$ Chemistry Department, Faculty of Science, Damanhour University, Damanhour, Egypt
}

\begin{abstract}
Functionalized enaminones; 3-N-(aryl)amino-1--oxo-cyclohex-2-ene-2-dithiocarboxylates cyclohex-2-en-1-ones and 3-N-(aryl)amino-2-(N-aryl)thioamido-cyclohex-2-en-1-ones were obtained upon reaction of 3-N(aryl)amino-5,5-dimethyl-1-oxo-cyclohex-2-enes with carbon disulfide in presence of sodium hydroxide in DMSO, followed by methylation with dimethyl sulfate or with phenyl and pbromophenyl isothiocyanates in toluene or under solvent-free condition, respectively. The cyclization of the dithioesters or the thioamides with hydrazine hydrate was accompanied by a displacement of the 3$\mathrm{N}$ - arylamine moiety by a hydrazine group to give 6-hydrazino-4,4-dimethyl-1,3,4,5-tetrahydroindazole7-thione or 3-N-(aryl)amino-4,5,6,7-tetrahydro- $1 \mathrm{H}$-indazole-4(5H)one respectively. Structure of the indazole derivatives formed was further confirmed from their reaction with acetone or p-nitrobenzaldehyde. The new structures were confirmed using ${ }^{1} \mathrm{HNMR},{ }^{13} \mathrm{CNMR}, 2 \mathrm{DNMR}, \mathrm{DEPT}$ experiments and mass spectra.
\end{abstract}

Keywords: Dimedone, Cyclic enaminones, Trans amination, Tetrahydroindazol-4-one, Dithiocarboxylate.

\section{Introduction}

Enaminones have received significant attention in organic synthesis due to their role as valuable precursors for the synthesis of a variety of bioactive heterocyclic compounds ${ }^{1-8}$. The respective dithiocarboxylate derivatives have been extensively utilized in the synthesis of heterocycles and thioglycosides ${ }^{9-14}$. Inazole a pharmacologically important scaffolds serve as structural motifs in drug molecules ${ }^{15-18}$. The diversely of indazole derivatives with a variety of functional groups were found to exhibit a broad spectrum of pharmacological activities ${ }^{15}$ such as antimicrobial 19-22, anti-angiogenic, antiproliferative ${ }^{23-24}$ and anti-inflammatory 20,25. Some indazole derivatives were evaluated for their inhibition activities against fibroblast growth factor receptor FGFR1 ${ }^{26}$, a bromodomain-containing protein 4 (BRD4) ${ }^{27}$, and as an inhibitor for filamentous temperature sensitive protein $\mathrm{Z}^{21}$ (FtsZ). A series of tetrahydroindazole were found to have antioxidant activity ${ }^{28}$.

Therefore, ongoing interest in the chemistry of enaminones we investigate herein the versatility of some enaminone dithiocarboxylates

*Corresponding author: El Sayed H. El Ashry

Email address: eelashry60@hotmail.com

DOI: http://dx.doi.org/10.13171/mjc761901713eshea and enaminone thioamides derived from dimedone as precursors for the synthesis of indazole derivatives.

\section{Results and Discussion}

Enaminones have two electron deficient centers at C-1 and C-3 while C-2 and amino functions are electron rich. They can thus react with both electrophiles and nucleophiles. Therefore, treatment of enaminones 1-6 ${ }^{29}$ with carbon disulfide in the presence of sodium hydroxide in dimethyl sulfoxide followed by methylation with dimethyl sulfate afforded the respective methyl 3-N-(aryl)amino-5,5dimethyl-1-oxo-cyclohex-2-ene-2-dithiocarboxylates 7-12, in 40-73\% yield ${ }^{11}$. The formation of the thioesters 7-12 rather than [3,1d]benzothiazine-2-thiones $\mathbf{1 3}$ was based on their spectral analyses. Thus, the mass spectrum of $\mathbf{1 1}$ showed a molecular ion peak at $\mathrm{m} / \mathrm{z} 339.1\left(\mathrm{M}^{+}\right)$ which in agreement with its molecular formula $\mathrm{C}_{16} \mathrm{H}_{18} \mathrm{NOS}_{2} \mathrm{Cl}$. Furthermore, the ${ }^{1} \mathrm{HNMR}$ spectra of 9, 11 and $\mathbf{1 2}$ showed an exchangeable $\mathrm{NH}$ proton at the downfield region at $\delta 13.17-$ $14.60 \mathrm{ppm}$ which excluded structure $\mathbf{1 3}$ and agreed with the assigned structure 7-12.

Received October 2, 2018

Accepted November 7, 2018

Published January 9, 2019 
The disappearance of the vinylic $\mathrm{C}-\mathrm{H}$ proton and the assignment of a characteristic singlet signal of S-Me protons at $\delta 3.36 \mathrm{ppm}$ of $\mathbf{9}$ measured in DMSO- $\mathrm{d}_{6}$ and at $\delta 2.55,2.57 \mathrm{ppm}$ for 11 and 12, respectively measured in $\mathrm{CDCl}_{3}$, also confirmed the assigned structure.

Attempted synthesis of the thiohyrazide derivatives 17 by the reaction of the enamino dithiocarboxylates 7-12 with hydrazine hydrate did not take place, but surprisingly, the products from the different dithiocarboxylates 7-12 have been found to be the same yellow crystalline product. Thus, an indazole ring structure $\mathbf{1 6}$ was formed rather than the expected thiohydrazide derivative $\mathbf{1 7}$ as deduced from its spectral data. The mass spectrum showed a molecular ion peak at $\mathrm{m} / \mathrm{z} 211.3\left(\mathrm{M}^{++}+1\right)$ which agreed with the molecular formula $\mathrm{C}_{9} \mathrm{H}_{14} \mathrm{~N}_{4} \mathrm{~S}$ (210.29). Furthermore, the ${ }^{1} \mathrm{H}$ NMR spectrum showed the presence of four exchangeable protons at $\delta 5.75$ $\operatorname{ppm}\left(\mathrm{NH}_{2}\right), 12.14$ and $12.70 \mathrm{ppm}(2 \mathrm{NH})$ as well as the absence of signals characteristic for aromatic protons. The three singlets at $\delta 1.00$, 2.40 and $2.68 \mathrm{ppm}$ were assigned for two equivalent methyl protons and two methylene protons respectively. The spectral data agreed with the formation of $\mathbf{1 6}$ which could be explained to proceed through three different pathways. Hydrazine could react with the carbonyl group of 7-12 to form the hydrazone derivative $\mathbf{1 4}$ that upon intramolecular cyclocondensation by nucleophilic displacement of the thiomethyl group will form indazole ring structure 15 that upon further nucleophilic displacement of the arylamino group by hydrazine gave $\mathbf{1 6}$ through an additionelimination reaction (rout i).

Alternatively, nucleophilic displacement of the thiomethyl group could take place by hydrazine to form the thiohydrazide $\mathbf{1 7}$ that spontaneously intermolecularly cyclized with the elimination of arylamine to form $\mathbf{1 8}$ whose reaction with hydrazine hydrate gave $\mathbf{1 6}$ (rout ii). However, as a consequence of the enaminones, nature ${ }^{30-32}$ the hydrazine would attack C-3 first with subsequent elimination of the arylamine moiety to form the intermediate $\mathbf{1 9}$ as in route iii. Intramolecular nucleophilic displacement of the thiomethyl group by $\mathrm{NH}_{2}$ of the hydrazine moiety would afford the indazole 18 which reacted with hydrazine to form 16. Accordingly, route iii represents the most convenient postulated mechanism for this reaction and in agreement with literature data $30-32$. The elimination of arylamine moiety explained the formation of the same product from each of 7-12. Structure of 16 was further confirmed from X-ray diffraction experiment of the hydrazone derivative $\mathbf{2 0}$ derived from the reaction of $\mathbf{1 6}$ with acetone that showed the structure of the product in full accord with $\mathbf{1 6}$. The acetone derivative $\mathbf{2 0}$ is identical with that reported earlier ${ }^{33}$.

Furthermore, the reaction of $\mathbf{1 6}$ with p-nitrobenzaldehyde in boiling ethanol gave a red crystalline hydrazone derivative $\mathbf{2 1}$. The ${ }^{1}$ HNMR spectrum of $\mathbf{2 1}$ showed in addition to the signals characteristic for the two methyl groups and the methylene protons of C-3 and C-5, two doublets at $\delta 8.11$ and 8.34 corresponding to the four aromatic protons. At the downfield region, only two exchangeable singlets at $\delta 12.59$ and $14.62 \mathrm{ppm}$ corresponding to two $\mathrm{NH}$ protons were assigned. Further support for the structure of compound 21 was verified from its ${ }^{13} \mathrm{C}$ NMR spectrum where the assignment of signals was supported by ${ }^{1} \mathrm{H},{ }^{1} \mathrm{H}$ COSY technique and ${ }^{1} \mathrm{H},{ }^{13} \mathrm{C}$ shift correlation. Thus, a signal corresponding to the two methyl groups appeared at $\delta_{\mathrm{c}} 26.8 \mathrm{ppm}$ which was correlated with their protons that resonated at $\delta 1.0 \mathrm{ppm}$ whereas the $\mathrm{C}-4$ was resonated at $\delta \mathrm{c} 33.1 \mathrm{ppm}$. Both of the methylene carbons, C-3 and C-5, were assigned based on their correlation with their protons that assigned at $\delta 2.49$ and $3.05 \mathrm{ppm}$ as well as from the DEPT experiment at $\delta_{\mathrm{c}} 36.1$ and $38.1 \mathrm{ppm}$. The azomethine carbon resonated at $\delta \mathrm{c} 152.6 \mathrm{ppm}$ as confirmed from its correlation with its proton at $\delta 8.74 \mathrm{ppm}$. Both of C-6a and C-3a were assigned at $\delta \mathrm{c} 106.2$ and $162.7 \mathrm{ppm}$, respectively, whereas, that of C-7 at $\delta \mathrm{c} 165.4 \mathrm{ppm}$.

The attempted reaction of enaminones $\mathbf{1 , 2}$ and 4 with phenyl isothiocyanate 22 and pbromophenyl isothiocyanate $\mathbf{2 3}$ in toluene under reflux gave the thioamides, 24-29, respectively in low to moderate yield (33-54\%) in addition to the recovery of the respective starting material. An improved yield was obtained when the reaction was carried out under solvent free conditions. Thus, heating of $\mathbf{1 , 2}$ and $\mathbf{4}$ with 22, and $\mathbf{1}$ with 23 without solvent at $160{ }^{\circ} \mathrm{C}$ for one hour afforded the respective thioamides $\mathbf{2 4 - 2 7}$, respectively in 79-95\% yield as a sole product. The formation of thioamides 24-29 rather than the thiourea derivatives $\mathbf{3 0}$ was established from their ${ }^{1}$ HNMR spectra. The disappearance of vinylic $\mathrm{H}-2$ proton and the assignment of two $\mathrm{D}_{2} \mathrm{O}$ exchangeable $\mathrm{NH}$ protons at $\delta 14.17-14.74$ and 15.81-15.97 ppm for compounds 25-29 whereas that of $\mathbf{2 4}$ were assigned at $\delta 16.71 \mathrm{ppm}$, confirmed the assigned structure. Both of the C- 4 and C- 6 protons of dimedone moiety were assigned as either singlet of four protons intensity at $\delta 2.48$ and $2.47 \mathrm{ppm}$, for compounds $\mathbf{2 6}$ and 29, respectively or as two singlets of two protons intensity each at $\delta 2.45-2.49$ and 2.49-2.50 ppm, for $24,25,27$ and 28 respectively. Signals characteristic for the thiocarbonyl group was 
observed in the ${ }^{13} \mathrm{CNMR}$ spectrum of $\mathbf{2 5}$ and $\mathbf{2 7}$ at $\delta_{\mathrm{c}} 189.85-189.87 \mathrm{ppm}$ whereas $\mathrm{C}-1(\mathrm{C}=\mathrm{O})$ was assigned at a higher frequency region at $\delta_{\mathrm{c}} 196.26-196.37 \mathrm{ppm}$. Both of C-2 and C-3 were resonated at $\delta_{\mathrm{c}} 104.72-104.74$ and 170.84-171.00 ppm, respectively. At the lower frequency region
C-4, C-5 and C-6 were assigned at $\delta_{\mathrm{c}} 30.25$ $30.29,27.82$ and 52.31-52.33 ppm, respectively. Furthermore, the mass spectra of 25, 27 and $\mathbf{2 9}$ were in full accord with their assigned structural formula (experimental).

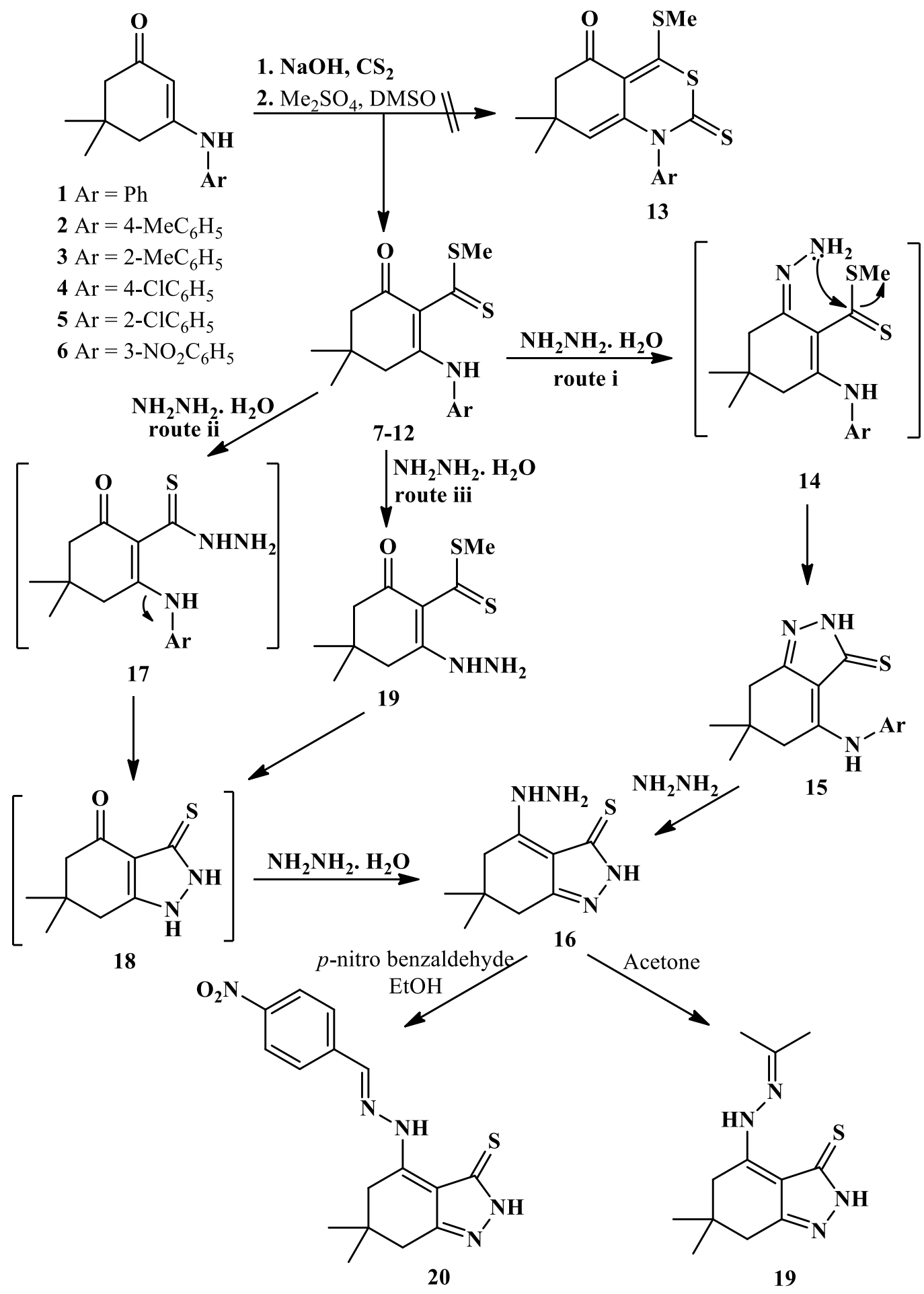

Scheme 1. Postulated mechanism for the synthesis of indazole derivatives. 


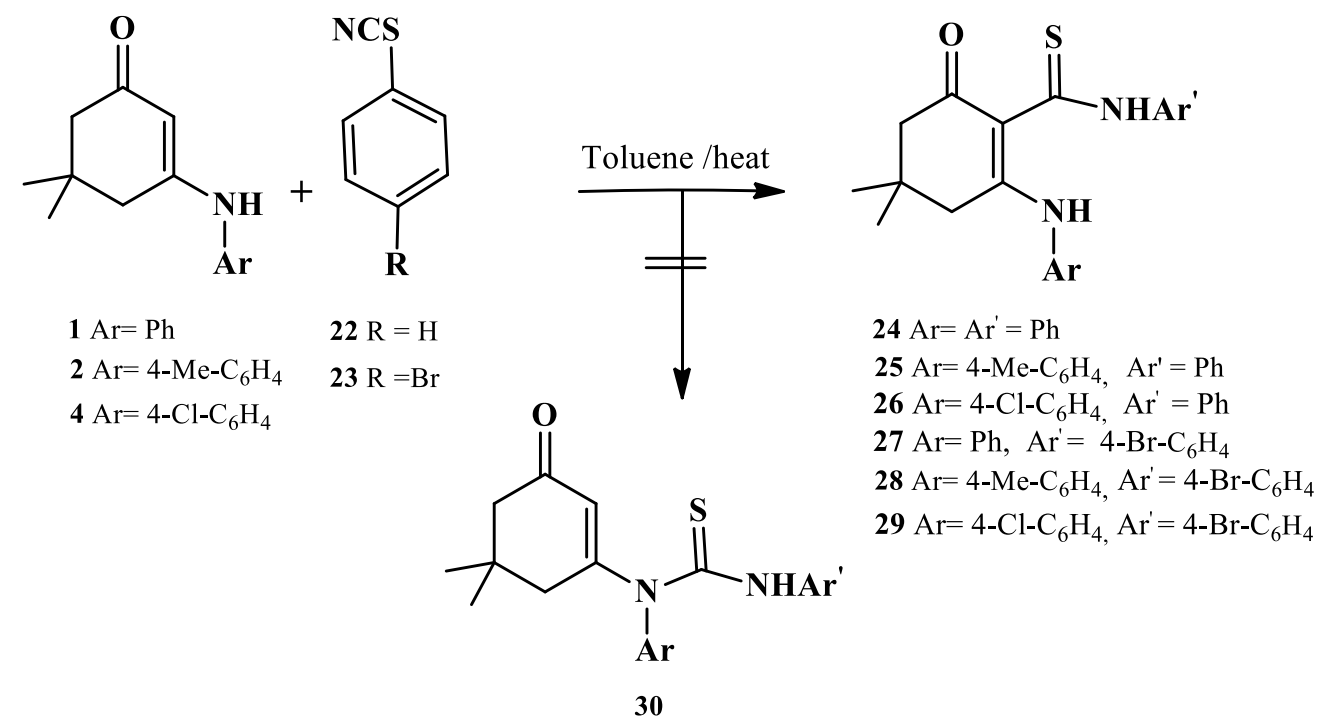

Scheme 2. Thioamides from enaminones

Treatment of different substrates 24-26 with hydrazine hydrate in ethanol under reflux for three hours afforded the same product 32. The formation of a single product can be explained only as a result of the removal of the arylamine moiety at C-3 to give one of two possible structures $\mathbf{3 2}$ or $\mathbf{3 3}$ respectively. Spectral analyses of the isolated products agreed with structure 32. The ${ }^{1} \mathrm{HNMR}$ showed only two $\mathrm{D}_{2} \mathrm{O}$ exchangeable $\mathrm{NH}$ protons at $\delta 7.96 \mathrm{ppm}$ as sharp singlet and $\delta 8.78 \mathrm{ppm}$ as broad one which ruled out structure 33. Furthermore, the removal of arylamine moiety was confirmed from the absence of 4-methyl group protons of $\mathbf{2 5}$ as well as its carbon in the ${ }^{13} \mathrm{CNMR}$ spectrum as well as the assignment of only five aryl protons at the aromatic area as two triplets and doublet at $\delta 6.99,7.36$ and $7.53 \mathrm{ppm}$, respectively. The ${ }^{13} \mathrm{CNMR}$ spectrum of $\mathbf{3 2}$ further supported the displacement of arylamine moiety and cyclization process. Only signals characteristic for one phenyl group carbons were observed at their appropriate position as well as the disappearance of the thione carbonyl carbon.

Moreover, the mass spectrum of $\mathbf{3 2}$ obtained from 26 showed a molecular ion peak at $\mathrm{m} / \mathrm{z}$ $254.31\left(\mathrm{M}^{+}-1\right)$ which in agreement with the assigned structure 32. Consequently, the formation of the indazole derivative $\mathbf{3 2}$ can be rationalized as a result of an addition-elimination reaction of hydrazine at $\mathrm{C}-3$ with subsequent elimination of the arylamine moiety with the formation of the intermediate $\mathbf{3 1}$ that intramolecularly cyclized through an additionelimination reaction at the thione group C-3 forming the indazole $32{ }^{34}$. Although we could not isolate compound 33, Jirkovshy ${ }^{34}$ in a similar reaction using benzylamine instead of arylamine could isolate $\mathbf{3 3}$ which upon hydrolysis with $\mathrm{HCl}$ gave 32 .

Furthermore compounds $\mathbf{2 7}$ and $\mathbf{2 8}$ were also subjected to the reaction with hydrazine hydrate to give also a single product 34 . The ${ }^{1} \mathrm{HNMR}$ showed only four aromatic protons at $\delta 7.37-7.48$ which moreover confirmed the removal of arylamine moiety at C-3. Also, two $\mathrm{D}_{2} \mathrm{O}$ exchangeable $\mathrm{NH}$ protons were assigned at $\delta 7.92$ and $8.87 \mathrm{ppm}$. The ${ }^{13} \mathrm{CNMR}$ spectra of $\mathbf{3 4}$ showed signals of C-3 at $\delta_{\mathrm{c}} 150.07 \mathrm{ppm}$ whereas $\mathrm{C}-7 \mathrm{a}$ and $\mathrm{C}-4 \mathrm{a}$ were assigned at $\delta 140.46$ and $104.57 \mathrm{ppm}$, respectively. Other signals are in their appropriate positions.

The formation of $\mathbf{3 2}$ rather than the hydrazine derivative $\mathbf{3 3}$ was elucidated from the recovery of $\mathbf{3 2}$ upon reaction with p-nitrobenzaldehyde. Under these circumstances we could prove that reaction of hydrazine hydrate with thioesters 7-12 or thioamides 24-27 proceed first by attack of hydrazine C-3 with subsequent elimination of arylamine followed by an intramolecular attack of the hydrazine $\mathrm{NH}_{2}$ to the thiocarbonyl group of thioester or thioamide with subsequent elimination of either methylmercaptan or hydrogen sulfide to form indazole ring structure. 
<smiles>CNC(=S)C1=C(N[AlH2])CC(C)(C)CC1=O</smiles><smiles>CC1(C)CC(=O)C(C(=S)NCCN)=C(N)C1</smiles><smiles>CC1(C)CC(=N)c2c(NCCN)n[nH]c2C1</smiles>

33<smiles>CCCCCC(N)N</smiles><smiles>CC1(C)CC(=O)c2c(Nc3ccccc3)n[nH]c2C1</smiles>

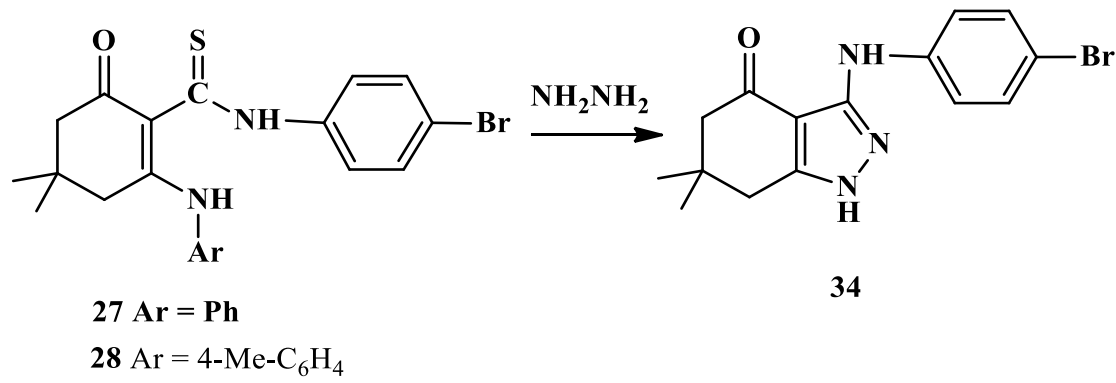

Scheme 3. 3-N-Arylamino-6,6-dimethyl-3-N-arylamino-6,7-dihydro-1H-indazole-4(5H)-one

\section{Conclusion}

The results considered in this work demonstrate the high synthetic utilities of enaminones as precursors for functionalized derivatives such as dithioesters and thioamides. Selective removal of the arylamino groups from these enaminone derivatives by hydrazine moiety with subsequent cyclization represents a unique method for the synthesis of indazole derivatives.

\section{Experimental}

Melting points were determined with a MelTemp apparatus and are uncorrected. TLC was performed on Baker-Flex silica gel 1B-F $(1.5-5 \mathrm{~cm})$ plates, and the spots were detected by UV light absorption. IR spectra were recorded for all compounds in a matrix of $\mathrm{KBr}$ with Perkin-Elmer 1430 spectrometer. ${ }^{1} \mathrm{H} \quad$ NMR spectra were recorded on Jeol spectrometer (500 $\mathrm{MHz}$ ), and Bruker $\mathrm{AC}(300 \mathrm{MHz})$ spectrometer and the ${ }^{13} \mathrm{C}$ NMR spectra were recorded on Joel spectrometer $(125 \mathrm{MHz})$ and Bruker AC spectrometer $(75 \mathrm{MHz})$. Chemical shifts $(\delta)$ are given in ppm relative to the signal for TMS as an internal standard. Mass spectra were recorded using electron ionization (EI) on a Finnigan MAT 312 spectrometer or Jeol (JMS.600H) instrument. Microanalysis was performed in the unit of microanalysis at Faculty of Science, Cairo University and unit of microanalysis at Faculty of Chemistry, Konstanz University, Germany.

Methyl 3-N-(aryl)amino-5,5-dimethyl-1-oxocyclohex-2-ene-2-dithiocarboxylate (7-12).

\section{General Method.}

To a well stirred cold solution of 1-6 (20 mmol) in DMSO (50 $\mathrm{mL})$ and sodium hydroxide solution in water $(20 \mathrm{mmol} ; 2 \mathrm{~mL})$, carbon disulfide $(30 \mathrm{mmol})$ was added in 30 minutes. The mixture was stirred for further 20 minutes below $10{ }^{\circ} \mathrm{C}$ whereby dimethyl sulfate (20 mmol) was added dropwise during $20 \mathrm{~min}$. The reaction mixture was left at room temperature for 1 hour with stirring, diluted with water $(200 \mathrm{~mL})$ and acidified with $10 \%$ hydrochloric acid. The resulting precipitate was collected by filtration, dried and recrystallized from methanol to give 7-12.

Methyl-5,5-dimethyl-1-oxo-3-N-(phenyl)aminocyclohex-2-ene-2-dithiocarboxylate (7). Yellow needles $\left(50 \%\right.$ yield); m. p 154-156 ${ }^{\circ} \mathrm{C}$; lit. ${ }^{11} \mathrm{~m}$. p $161-164{ }^{\circ} \mathrm{C}$.

Methyl-5,5-dimethyl-3-N-(4-methylphenyl)amino-1-oxo-cyclohex-2-ene-2-dithiocarboxylate (8). 
Yellow needles (43\% yield); m. p. $180-182^{\circ} \mathrm{C}$, lit. ${ }^{11}$ m. p. $185-187^{\circ} \mathrm{C}$.

\section{Methyl-5,5-dimethyl-3-N-(2-methylphenyl)- amino-1-oxo-cyclohex-2-ene-2-dithiocarbo- xylate (9). \\ Orange needles (58\% yield); m. p. $188-190{ }^{\circ} \mathrm{C}$. IR (KBr) $3400(\mathrm{NH}) ; 1652 \mathrm{~cm}^{-1}$ (CO); \\ ${ }^{1} \mathrm{H}$ NMR (DMSO- $\left.d_{6}, 500 \mathrm{MHz}\right): \delta_{\mathrm{H}} \mathrm{ppm}=0.95$ (s, $6 \mathrm{H}, 2 \mathrm{Me}), 1.9\left(\mathrm{~s}, 2 \mathrm{H}, \mathrm{CH}_{2}\right), 2.03(\mathrm{~s}, 2 \mathrm{H}$, $\mathrm{CH}_{2}$ ), 2.5 (s, $3 \mathrm{H}, \mathrm{Me}$ ), 3.36 (s, $3 \mathrm{H}, \mathrm{SMe}$ ), 6.5 (d, 1H, J 7.65 Hz, Ar-H), 6.99 (t, 1H, J 7.65 Hz, Ar-H), 7.14-7.29 (m, 2 H, Ar-H), 14.6 (s, 1H, $\mathrm{D}_{2} \mathrm{O}$ exchangeable $\mathrm{HN}$ ). \\ Analysis calcd. for $\mathrm{C}_{17} \mathrm{H}_{21} \mathrm{~N}$ O $\mathrm{S}_{2}$ (319.478): C, 63.91; H, 6.62; N, 4.38; S 20.07. Found: C, 63.88; H, 6.51; N, 4.29; S, 20.08.}

Methyl-5,5-dimethyl-3-N-(4-chlorophenyl)amino-1-oxo-cyclohex-2-ene-2-dithiocarboxylate (10).

Yellow needles (40\% yield); m. p. $158-160^{\circ} \mathrm{C}$, lit. ${ }^{11} \mathrm{~m}$. p. $160-162{ }^{\circ} \mathrm{C}$.

Methyl 5, 5-dimethyl-3-N-(2-chlorophenyl)amino-1-oxo-cyclohex-2-ene-2-dithiocarboxylate (11).

Orange needles $(73 \%$ yield $)$; m. p. $162-164{ }^{\circ} \mathrm{C}$. IR (KBr) $3400(\mathrm{NH}) ;{ }^{1} \mathrm{H}$ NMR $\left(\mathrm{CDCl}_{3}, 500\right.$ $\mathrm{MHz}): \delta_{\mathrm{H}} \mathrm{ppm}=1.01(\mathrm{~s}, 6 \mathrm{H}, 2 \mathrm{Me}), 2.36(\mathrm{~s}, 2$ $\left.\mathrm{H}, \mathrm{CH}_{2}\right), 2.43\left(\mathrm{~s}, 2 \mathrm{H}, \mathrm{CH}_{2}\right), 2.55$ (s, $\left.3 \mathrm{H}, \mathrm{SMe}\right)$, 7.23 (dd, $1 \mathrm{H}, \mathrm{J} 9.2 \mathrm{~Hz}, \mathrm{Ar}-\mathrm{H}), 7.34-7.35$ (m, 2 H, Ar-H), 7.52 (dd, 1 H, J 9.95 Hz, Ar-H), 13.17 (s, $1 \mathrm{H}, \mathrm{D}_{2} \mathrm{O}$ exchangeable, $\left.\mathrm{NH}\right)$. MS (EI), m/z (\%): $339.1\left(30, \mathrm{M}^{+}\right), 292\left(100, \mathrm{M}^{+}\right.$- $\left.\mathrm{SMe}\right)$. Anaysisl calcd. for $\mathrm{C}_{16} \mathrm{H}_{18} \mathrm{Cl} \mathrm{N} \mathrm{O} \mathrm{S}$ (339.895): C, 56.54; H, 5. 34; N, 4.12; S, 18.87. Found: C, 56.30; H, 5. 58; N, 4.31; S, 18.75 .

Methyl 5,5-dimethyl -3-N(3-nitrophenyl)amino-1-oxo-cyclohex-2-ene-2-dithiocarboxylate (12).

Yellow needles (60\% yields); m. p. 176-178 ${ }^{\circ} \mathrm{C}$. ${ }^{1} \mathrm{H} \mathrm{NMR}\left(\mathrm{CDCl}_{3}, 500 \mathrm{MHz}\right): \delta_{\mathrm{H}} \mathrm{ppm}=1.04(\mathrm{~s}, 6$ $\mathrm{H}, 2 \mathrm{Me}), 2.46$ (s, $\left.2 \mathrm{H}, \mathrm{CH}_{2}\right), 2.52\left(\mathrm{~s}, 2 \mathrm{H}, \mathrm{CH}_{2}\right)$, 2.57 (s, $3 \mathrm{H}, \mathrm{SMe}$ ), 7.53, (dd, $1 \mathrm{H}, \mathrm{J} 6.9 \mathrm{~Hz}, \mathrm{Ar}-$ H), (t, 1H, J $8.4 \mathrm{~Hz}, \mathrm{Ar}-\mathrm{H}), 8.06$ (t, $1 \mathrm{H}, \mathrm{J} 2.3 \mathrm{~Hz}$, Ar-H), 8.22 (dd,1 H, J 6.9 Hz, J $1.5 \mathrm{~Hz}, \mathrm{Ar}-\mathrm{H})$, 13.56 (s, $1 \mathrm{H}, \mathrm{D}_{2} \mathrm{O}$ exchangeable, $\mathrm{NH}$ ).

Analysis calcd. for $\mathrm{C}_{16} \mathrm{H}_{18} \quad \mathrm{~N}_{2} \mathrm{O}_{3} \mathrm{~S}_{2}$ (350.45): C, 54.83; H, 5.17; N, 7.99; S, 18.29. Found: C, 54.71; H, 4.97; N, 7.88; S, 18.01 .

6-Hydrazino-4,4-dimethyl-1,3,4,5-tetrahydroindazol-7-thione (16).

A solution of 7-12 $(0.9 \mathrm{mmol})$ in ethanol $(15 \mathrm{~mL})$ was treated with hydrazine hydrate $(2 \mathrm{~mL})$. The mixture was heated under reflux for $1 \mathrm{hr}$., then left to cool. The product was filtered and crystalized from methanol to give $\mathbf{1 6}$ in $40 \%$ yield from 7, $58 \%$ yield from $\mathbf{8 , 4 0 \%}$ yield from 9, $73 \%$ yield from 10, $48 \%$ from $\mathbf{1 1}$ and $60 \%$ from 12, m. p. $177-179^{\circ} \mathrm{C}$; IR (KBr) $3160(\mathrm{NH})$; $1664 \mathrm{~cm}^{-1}(\mathrm{C}=\mathrm{N}) ;{ }^{1} \mathrm{H}$ NMR (DMSO- $d_{6}, 300$ $\mathrm{MHz}): \delta_{\mathrm{H}} \mathrm{ppm}=1.0(\mathrm{~s}, 6 \mathrm{H}, 2 \mathrm{Me}), 2.40(\mathrm{~s}, 2 \mathrm{H}$, $\left.\mathrm{CH}_{2}\right), 2.68\left(\mathrm{~s}, 2 \mathrm{H}, \mathrm{CH}_{2}\right), 5.75\left(\mathrm{~s}, 2 \mathrm{H}, \mathrm{D}_{2} \mathrm{O}\right.$ exchangeable $\left.\mathrm{NH}_{2}\right), 12.14,12.70\left(2 \mathrm{~s}, 2 \mathrm{H}, \mathrm{D}_{2} \mathrm{O}\right.$ exchangeable, $2 \mathrm{NH}$ ).

Ms (EI) m/z (\%) $211.3\left(14, \mathrm{M}^{+\cdot}+1\right), 179\left(22, \mathrm{M}^{+\cdot}\right.$ $\mathrm{NH}_{2} \mathrm{NH}_{2}$ ).

Analysis calcd. for $\mathrm{C}_{9} \mathrm{H}_{14} \mathrm{~N}_{4} \mathrm{~S}$ (210.269): C, 51.39; H, 6.71; N, 26.64. Found: C, 51.72; $\mathrm{H}, 6.41 ; \mathrm{N}, 26.63$.

\section{6,6-Dimethyl-4-(2-(propan-2-ylidene)-} hydrazinyl)-6,7-dihydro-2H-indazole-3(5H)thione (20).

A solution of 6-hydrazino-4, 4-dimethyl1,3,4,5-tetrahydroindazol-7-thione (16) $(0.20 \mathrm{~g})$ in methanol $(20 \mathrm{~mL})$ was treated with acetone $(5 \mathrm{~mL})$ and then heated under reflux for $1 \mathrm{~h}$. The product was recrystallized from a mixture of acetone and methanol to give yellow crystals, m. p. $262^{\circ} \mathrm{C}$, identical with that reported earlier, lit. ${ }^{34}$ m. p. $262^{\circ} \mathrm{C}$.

\section{4,4-Dimethyl-6-(4-nitrophenyl)hydrazono- 1,3,4,5-tetrahydroindazol-7-thione (21).}

A solution of $16 \quad(0.6 \quad$ mmol $)$ and p-nitrobenzaldehyde $(0.68 \mathrm{mmol})$ in methanol $(15 \mathrm{~mL})$ was heated under reflux for 20 minutes. A red crystals were separated, filtered while hot, washed with methanol and recrystallized from methanol/ dimethylformamide to give $\mathbf{2 1}$

(50\% yield); m. p. $236-238^{\circ} \mathrm{C}$;

IR (KBr) 3404, $3112(\mathrm{NH})$ and $1618 \mathrm{~cm}^{-1}(\mathrm{C}=\mathrm{N})$, ${ }^{1} \mathrm{H}$ NMR (DMSO- $d_{6}, 300 \mathrm{MHz}$ ): $\delta_{\mathrm{H}} \mathrm{ppm}=1.0$ (s, $6 \mathrm{H}, 2 \mathrm{Me}), 2.49$ (s, $\left.2 \mathrm{H}, \mathrm{CH}_{2}\right), 3.05(\mathrm{~s}, 2 \mathrm{H}$, $\left.\mathrm{CH}_{2}\right), 8.11(\mathrm{~d}, 2 \mathrm{H}, \mathrm{J}=8.6 \mathrm{~Hz}, \mathrm{Ar}-\mathrm{H}), 8.34$ (d, 2 $\mathrm{H}, \mathrm{J}=8.6 \mathrm{~Hz}, \mathrm{Ar}-\mathrm{H}), 8.74(\mathrm{~s}, 1 \mathrm{H}, \mathrm{CH}=\mathrm{N}), 12.59$, $14.62\left(2 \mathrm{~s}, 2 \mathrm{H}, \mathrm{D}_{2} \mathrm{O}\right.$ exchangeable, $\left.2 \mathrm{NH}\right)$;

${ }^{13} \mathrm{C}$ NMR $\delta_{\mathrm{c}}$ ppm: 26.8 (2 Me), 33.1 (C-4), 36.1, 38.1 (C-3, C-5), 106.2 (C-6a), 122.9 (C-2, C-5, Ar-C), 137.5 (C-4, Ar-C) 147.5 (C-1, Ar-C), $150.4(\mathrm{C}-6), 152.6(\mathrm{HC}=\mathrm{N}), 162.7(\mathrm{C}-3 \mathrm{a}), 165.4$ (C-7).

Anaysis calcd. for $\mathrm{C}_{16} \mathrm{H}_{17} \mathrm{~N}_{5} \mathrm{SO}_{2}$ (343.406): C, 55.95; H, 4.99; N, 20.39. Found: C, 55.77; $\mathrm{H}, 4.78 ; \mathrm{N}, 20.25$.

\section{3-N-(Aryl)amino-2-(N-aryl)thioamido-5,5- dimethylcyclohex-2-en-1-one (24-29).}

General method a. A mixture of enamines 1, 2 and $4(10 \mathrm{mmol})$, and aryl isothiocyanate 22 and $23(10 \mathrm{mmol})$ in toluene $(20 \mathrm{~mL})$ was refluxed for $20 \mathrm{hr}$. The reaction mixture was left to cool, and the unreacted enamines were separated by filtration. The filtrate was concentrated under reduced pressure. The syrup obtained was triturated with methanol to give 24-29 that were recrystallized from ethanol.

General method b. A mixture of enamines 1, 2 and $4(10 \mathrm{mmol})$ and aryl isothiocyanate 22 and 
23 (10 mmol) was heated under reflux for $1 \mathrm{hr}$ in an oil bath at $160{ }^{\circ} \mathrm{C}$. The glassy product obtained was then crystallized from ethanol to give 24-27.

\section{5,5-Dimethyl-3-N-(phenyl)amino-2-(N- phenyl)thioamido-cyclohex-2-en-1-one (24). It was obtained as pale yellow crystals in $47 \%$ yield from method a and in $92 \%$ yield from method b; mp $160-162{ }^{\circ} \mathrm{C}$ lit. ${ }^{35} \mathrm{~m}$. p. $168-169^{\circ} \mathrm{C}$; ${ }^{1} \mathrm{H} \mathrm{NMR}\left(\mathrm{CDCl}_{3}, 500 \mathrm{MHz}\right): \delta_{\mathrm{H}} \mathrm{ppm}=1.04(\mathrm{~s}, 6$ $\mathrm{H}, \mathrm{Me}$ ), 2.49 (s, $4 \mathrm{H}, 2 \mathrm{CH}_{2}$ ), 7.17 (d, $\left.2 \mathrm{H}, \mathrm{Ar}-\mathrm{H}\right)$, 7.24-7.27 (m, $2 \mathrm{H}, \mathrm{Ar}-\mathrm{H}), 7.34-7.48$ (m, $5 \mathrm{H}, \mathrm{Ar}-$ $\mathrm{H}), 16.7\left(2 \mathrm{~s}, 2 \mathrm{H}, \mathrm{D}_{2} \mathrm{O}\right.$ exchangeable $\left.\mathrm{NH}\right)$. Analysis calcd. for $\mathrm{C}_{21} \mathrm{H}_{22} \mathrm{~N}_{2} \mathrm{OS}$ (350.476): C, 71.96; H, 6.33; N, 7.99; S, 9.15. Found: C, 71.80; H, 6.20; N, 7.65; S, 8.85.}

\section{5,5-Dimethyl-2-(N-phenyl)thioamido-3-(4- methylphenyl)amino-cyclohex-2-en-1-one (25).}

It was obtained as colorless crystals in 33\% yield from method a and in $79 \%$ yield from method b; m. p. $162-164^{\circ} \mathrm{C}$;

${ }^{1} \mathrm{H}$ NMR $\left(\mathrm{CDCl}_{3}, 500 \mathrm{MHz}\right) \delta_{\mathrm{H} p m}=1.03$ (s, $6 \mathrm{H}, 2 \mathrm{Me}), 2.39$ (s, $3 \mathrm{H}, \mathrm{Me}), 2.46(\mathrm{~s}, 2 \mathrm{H}$, $\left.\mathrm{CH}_{2}\right), 2.49$ (s, $\left.2 \mathrm{H}, \mathrm{CH}_{2}\right), 7.07$ (d, $2 \mathrm{H}, \mathrm{J}=8.6 \mathrm{~Hz}$, Ar-H), 7.22-7.26 (m, $3 \mathrm{H}$, Ar-H), 7.39 (t, $2 \mathrm{H}$, $\mathrm{J}=7.65$, Ar-H), $7.46(\mathrm{~d}, 2 \mathrm{H}, \mathrm{J}=7.3 \mathrm{~Hz}, \mathrm{Ar}-\mathrm{H})$, $14.17,15.91\left(2 \mathrm{~s}, 2 \mathrm{H}, \mathrm{D}_{2} \mathrm{O}\right.$ exchangeable $\left.2 \mathrm{NH}\right)$. ${ }^{13} \mathrm{CNMR}\left(\mathrm{CDCl}_{3}\right) \delta_{\mathrm{c}} \mathrm{ppm}: 21.11(4-\mathrm{Me}), 27.82$ (2Me), 30.25 (C-5), 42.93 (C-4), 52.31 (C-6), 104.72 (C-2), 119.63, 125.89, 127.79, 130.26, 131.80, 134.14, 137.87, 138.27 (Ar-C0, 171.00 (C-3), 189.85 (C=S), 196.26 (C-1).

MS, m/z (\%): $364.2\left(33, \mathrm{M}^{+\cdot}\right), 331.2\left(78, \mathrm{M}^{+.}\right.$ $\mathrm{SH}), 241.2\left(100,331.2^{+}\right.$- $\left.\mathrm{PhN}\right)$.

Analysis calcd. for $\mathrm{C}_{22} \mathrm{H}_{24} \mathrm{~N}_{2} \mathrm{OS}$ (364.496): C, 72.49; H, 6.64; N, 7.69; S, 8.84. Found: C 71.99; H 6.56; N 7.83; S 8.69.

3-(4-Chlorophenyl)amino-5,5-dimethyl-2-(Nphenyl)thioamido-cyclohex-2-en-1-one (26).

It was obtained as pall yellow crystals in 33\% yield from method a and in $96 \%$ yield from method b ; m. p. $166-168^{\circ} \mathrm{C}$;

${ }^{1} \mathrm{H}$ NMR $\left(\mathrm{CDCl}_{3}, 500 \mathrm{MHz}: \delta_{\mathrm{H}} \mathrm{ppm}=1.04\right.$ (s, $6 \mathrm{H}, 2 \mathrm{Me}), 2.48\left(\mathrm{~s}, 4 \mathrm{H}, 2 \mathrm{CH}_{2}\right), 7.13(\mathrm{~d}, 2 \mathrm{H}$, $\mathrm{J}=8.6 \mathrm{H}$, Ar-H), 7.24-7.27 (m, $2 \mathrm{H}$, Ar-H $)$, 7.38-7.42 (m, $3 \mathrm{H}$, Ar-H), 7.46 (d, $2 \mathrm{H}, \mathrm{J}=7.65$, Ar-H), 14.61, 15.97 (2s, 2H, $\mathrm{D}_{2} \mathrm{O}$ exchangeable $\mathrm{NH})$.

Analysis calcd. for $\mathrm{C}_{21} \mathrm{H}_{21} \mathrm{ClN}_{2} \mathrm{OS}$ (348.923): C, 65.52; H, 5.50; N, 7.28; S, 8.33. Found: C, 65.44; H, 5.56; N, 7.48; S, 8.54.

\section{2-(N-4-Bromophenyl)thioamido-5,5-} dimethyl-3-N-(phenyl)amino-cyclohex-2-en1-one (27).

It was obtained as colorless crystals in $33 \%$ yield from method a and in $95 \%$ yield from method $b$; m. p. $202-204^{\circ} \mathrm{C}$;
${ }^{1} \mathrm{H} \mathrm{NMR}\left(\mathrm{CDCl}_{3}, 500 \mathrm{MHz}\right): \delta_{\mathrm{H}} \mathrm{ppm}=1.03(\mathrm{~S} 6$ $\mathrm{H}, 2 \mathrm{Me}), 2.46\left(2,2 \mathrm{H}, \mathrm{CH}_{2}\right), 2.50\left(\mathrm{~s}, 2 \mathrm{H}, \mathrm{CH}_{2}\right)$, 7.19 (d, $2 \mathrm{H}, \mathrm{J}=7.65 \mathrm{~Hz}, \operatorname{Ar}-\mathrm{H}), 7.38(\mathrm{~d}, 3 \mathrm{H}$, $\mathrm{J}=8.7 \mathrm{~Hz}, \mathrm{Ar}-\mathrm{H}), 7.45$ (t, $2 \mathrm{H}, \mathrm{J}=7.65 \mathrm{~Hz}, \mathrm{Ar}-\mathrm{H})$ $7.51(\mathrm{~d}, 2 \mathrm{H}, \mathrm{J}=8.6 \mathrm{~Hz}, \mathrm{Ar}-\mathrm{H}), 14.74,15.93$ (2s, $2 \mathrm{H}, \mathrm{D}_{2} \mathrm{O}$ exchangeable $2 \mathrm{NH}$ ).

${ }^{13} \mathrm{CNMR}\left(\mathrm{CDCl}_{3}\right) \delta_{\mathrm{c}}$ ppm: 27.81 (2Me), 30.29 (C-5), 43.03 (C-4), 52.33 (C-6)104.74 (C-2), 119.73, 126.15, 127.78, 127.82, 129.69, 131.82, 136.83, 138.22 (Ar-C), 170.84 (C-3), 189.87 $(\mathrm{C}=\mathrm{S}) 196.37 \quad(\mathrm{C}=\mathrm{O})$.

MS: m/z (\%) $430.3\left(10, \mathrm{M}^{+.}+1\right), 397.3\left(\mathrm{M}^{+} \cdot-\mathrm{H}_{2} \mathrm{~S}\right.$ ), $241\left(25,397.3-\mathrm{C}_{6} \mathrm{H}_{4} \mathrm{Br}\right)$.

Analysis calcd. for $\mathrm{C}_{21} \mathrm{H}_{21} \mathrm{Br} \mathrm{N} \mathrm{N}_{2} \mathrm{OS}$ (429.382): C, 58.74; H, 4.93; N, 6.52; S, 7.47. Found: C, 58.64; H, 4.57; N, 6.19; S, 7.18.

\section{2-N-(4-Bromophenyl)thioamido-6,6-} dimethyl-3-N-(4-methylphenyl)aminocyclohex-2-en-1-one (28).

It was obtained as pale yellow crystals in $37 \%$ yield from method a; m.p. 208-210 ${ }^{\circ} \mathrm{C}$

${ }^{1} \mathrm{H}$ NMR $\left(\mathrm{CDCl}_{3}, 500 \mathrm{MHz}\right): \delta_{\mathrm{H}} \mathrm{ppm}=1.03$ (s, $6 \mathrm{H}, 2 \mathrm{Me}), 2.39(\mathrm{~s}, 3 \mathrm{H}, \mathrm{Me}), 2.46(\mathrm{~s}, 2 \mathrm{H}$, $\left.\mathrm{CH}_{2}\right), 2.49$ (s, $\left.2 \mathrm{H}, \mathrm{CH}_{2}\right), 7.06(\mathrm{~d}, 2 \mathrm{H}, \mathrm{J}=8.65 \mathrm{H}$, Ar-H), 7.25 (m, 3 H, Ar-H), 7.38 (d, 2 H, J= 8.6 $\mathrm{Hz}), 7.50(\mathrm{~d}, 2 \mathrm{H}, \mathrm{J}=8.6 \mathrm{~Hz}), 14.73,15.81$ (2s, 2H, $\mathrm{D}_{2} \mathrm{O}$ exchangable, $\left.2 \mathrm{NH}\right)$.

MS, m/z (\%): 442.6 (15.2, $\mathrm{M}^{+.}$), 409.1 (20.4, $\left.\mathrm{M}^{+}-\mathrm{H}_{2} \mathrm{~S}\right), 272.2\left(45, \mathrm{M}^{+} \cdot-\mathrm{Br}_{-} \mathrm{C}_{6} \mathrm{H}_{4}-\mathrm{N}\right)$.

Analysis calcd. For $\mathrm{C}_{22} \mathrm{H}_{23} \mathrm{~N}_{2}$ (443.402): C, 59.59; H, 5.23; N, 6.32; S, 7.23. Found: C, 59.09; H, 5.27; N, 5.98; S, 6.94.

\section{2-N-(4-Bromophenyl)thioamido-3-N-(4-} chlorophenyl)amino-5,5-dimethyl-cyclohex-2en-1-one (29).

It was obtained as pall yellow crystal in 54\% yield from method a; m. p. $185-187{ }^{\circ} \mathrm{C}$;

${ }^{1} \mathrm{H} \mathrm{NMR}\left(\mathrm{CDCl}_{3}, 500 \mathrm{MHz}\right): \delta_{\mathrm{H} p m}=1.04$ (s $6 \mathrm{H}, 2 \mathrm{Me}), 2.47$ (s, $\left.4 \mathrm{H}, 2 \mathrm{CH}_{2}\right), 7.13(\mathrm{~d}, 2 \mathrm{H}$, $\mathrm{J}=8.65 \mathrm{~Hz}, \mathrm{Ar}-\mathrm{H}), 7.37(\mathrm{~d}, 2 \mathrm{H}, \mathrm{J}=8.6 \mathrm{~Hz}, \mathrm{Ar}-$ $\mathrm{H}), 7.43(\mathrm{~d}, 2 \mathrm{H}, \mathrm{J} 8.65, \operatorname{Ar}-\mathrm{H}), 7.51(\mathrm{~d}, 2 \mathrm{H}$, $\mathrm{J}=8.6 \mathrm{~Hz}$, Ar-H), 7.67 (d, $1 \mathrm{H}, \mathrm{J}=8.6 \mathrm{~Hz}, \mathrm{Ar}-\mathrm{H})$, 14.67, 15.91 ( $2 \mathrm{~s}, 2 \mathrm{H}, \mathrm{D}_{2} \mathrm{O}$ exchangeable, N-H). Analysis calcd. For $\mathrm{C}_{21} \mathrm{H}_{20} \mathrm{BrCl} \mathrm{N} \mathrm{N}_{2} \mathrm{OS}$ (463.829): C, 54.37; H, 4.35; N, 6.04; S, 6.91. Found: C, 54.64; H, 4.01; N, 5.87; S, 6.95.

\section{3-N-(Aryl)amino-6,6-dimethyl-6,7-dihydro-}

1H-indazole-4 $(5 \mathrm{H})$ ones $(32)$ and $(34)$.

A mixture of compounds $\mathbf{2 4 - 2 8}(0.2 \mathrm{mmol})$ and hydrazine hydrate in ethanol $(10 \mathrm{~mL})$ was heated under reflux for $3 \mathrm{~h}$. The resulting solution was then concentrated under reduced pressure. The solid obtained was filtered off and crystallized for ethanol.

6,6-Dimethyl-3-N-(phenyl)amino-6,7dihydro-1H-indazole-4(5H)one (32): 
It was obtained as colorless crystals in 69, 46 and $45 \%$ yield from 24, 25 and 26, respectively, m. p. 272-273 ${ }^{\circ} \mathrm{C}$; lit ${ }^{35}$ m.p. $270-271^{\circ} \mathrm{C}$,

IR $3464(\mathrm{NH}) ; 1618 \mathrm{~cm}^{-1}(\mathrm{C}=\mathrm{O})$,

${ }^{1} \mathrm{HNMR}\left(\mathrm{CDCl}_{3}, 500 \mathrm{MHz}\right): \delta \mathrm{H} \mathrm{ppm}=1.17$ (s, 6H, 2Me), $2.40\left(\mathrm{~s}, 2 \mathrm{H}, \mathrm{CH}_{2}\right), 2.68(\mathrm{~s}, 2 \mathrm{H}$, $\left.\mathrm{CH}_{2}\right), 6.99(\mathrm{t}, 1 \mathrm{H}, \mathrm{Ar}-\mathrm{H}), 7.33-7.36(\mathrm{~m}, 2 \mathrm{H}$, Ar-H), 7.53 (d, 2H, Ar-H), 7.96 (s, 1H, D $2 \mathrm{O}$ exchangeable, $\mathrm{NH})$,

${ }^{13} \mathrm{CNMR}\left(\mathrm{CDCl}_{3}\right) \quad \delta \mathrm{c}$ ppm: $28.54(2 \mathrm{Me}), 35.42$ (C-6), 36.14 (C-7), 51.70 (C-5), 104.80 (C-4a), 117.38, 121.32, 129.19, 140.55 (Ar-C), 155.2 (C-3), 193.52 (C-4), MS, m/z (\%): 254.1 $\left(40, \mathrm{M}^{+}-1\right), 162\left(\mathrm{M}^{+} \cdot-\mathrm{PhNH}_{2}\right)$.

Analysis calcd for $\mathrm{C}_{15} \quad \mathrm{H}_{17} \quad \mathrm{~N}_{3} \mathrm{O}$ (255.31): C, 70.56; H, 6.71; N, 16.46. Found: C, 70.44; $\mathrm{H}, 6.50 ; \mathrm{N}, 16.30$.

\section{3-N-(4-Bromophenyl)amino-6,6-dimethyl- 6,7-dihydro-1H-indazole-4(5H)one (34).}

It was obtained as colorless crystals in $71 \%$ yield from 27 and $50 \%$ yield from 28; m.p. 256-258 ${ }^{\circ} \mathrm{C}$; ${ }^{1} \mathrm{HNMR}\left(\mathrm{CDCl}_{3}, 300 \mathrm{MHz}\right): \delta \mathrm{H}$ $\mathrm{ppm}=1.10(\mathrm{~s}, 6 \mathrm{H}, 2 \mathrm{Me}), 2.37\left(\mathrm{~s}, 2 \mathrm{H}, \mathrm{CH}_{2}\right), 2.67$ (s, 2H, $\mathrm{CH}_{2}$ ), 7.42-7.48 (m, 4H, Ar-H), 7.92 (s, $1 \mathrm{H}, \mathrm{D}_{2} \mathrm{O}$ exchangeable, $\left.\mathrm{NH}\right), 8.87\left(\mathrm{bs}, 1 \mathrm{H}, \mathrm{D}_{2} \mathrm{O}\right.$ exchangeable, NH); ${ }^{13} \mathrm{CNMR}$ (DMSO-d 6 ) $\delta \mathrm{c}$ ppm: 28.46 (2Me), 34.56 (C-6), 36.21 (C-7), 51.92 (C-5), 104.57 (C-4a), 111.51, 119.19, 131.50, 132.02, 132.26, 141.29 (Ar-C), 150.02 (C-7a), 150.07 (C-3), 192.99 (C-4).

Anaysis calcd. for $\mathrm{C}_{15} \mathrm{H}_{16} \mathrm{Br} \mathrm{N} \mathrm{N}_{3} \mathrm{O}$ (334.216) C, 53.91; H, 4.83; N, 12.57. Found: C, 53.74; $\mathrm{H}, 4.51 ; \mathrm{N}, 12.30$.

\section{References}

1- E. S. H El Ashry, L.F. Awad, Y. El kilany, E. I. Ibrahim, Dimedone: A Versatile Precursor for Annulated Heterocycles, Adv. Heterocycl. Chem., 2009, 98, 3- 141.

2- M. S. Bashandy, Synthesis, Anti-Breast Cancer and Molecular Docking of Some Heterocycles Incorporating N, NDibenzylbdenzensulfonamide, Int. J. Adv. Res., 2014, 2, 436-469

3- E. A. Ragab, N. H. Metwally, M. S. Mohamed, Synthesis of Some Novel Pyrazolo[1,5-[a]quinazolines and Their Fused Derivatives, Synth. Commun., 2017, 47,148-158.

4- S.S. Asma; B. Kalluraya, Enaminones as Building Block: Synthesis of Novel Substituted Pyrazoles as Possible Antioxidants, Indian J. chem., 2016, 55B, 501.

5- Y. Zhao, Q. Duan, Y. Zhou, Q. Yao, Z. Li, Gold-Catalyzed Chemo- and Diastereoselective $\mathrm{C}\left(\mathrm{sp}^{2}\right)$ - Functionalization of Enaminones for the Synthesis of Pyrrolo[3,4-c]-quinolin- 1-one Derivatives, Org. Biomol. Chem., 2016, 14, 2177-2181.

6- A.A. Hassan, Heterocyclic Synthesis Via Enaminones: Synthesis and Molecular Docking Studies of Some Novel Heterocyclic Compounds Containing Sulfonamide Moiety, Inter. J. Org. Chem., 2014, 4, 68-81.

7- L. Long, Y. Shao, Y. Li, Y. Liu, Y. Li, LDA-Promoted Synthesis of 3-Amino Furans by Selective Lithiation of Enaminones, J. Org. Chem., 2015, 80, 12641-

8- L.V. Sokolenko, Y. L. Yagupolskii, L. S.Kumanetska, J. Marrot, E. Magnier, V. O. Lipetskij, I. V. Kalinin, $\mathrm{CF}_{3}(\mathrm{O})_{\mathrm{n}^{-}}$ Containing enaminones as Precursors for The Synthesis of Pyrimidine-4(3H)- ones, Tetrahedron Lett., 2017, 58, 1308- 1311.

9- Y, Tominaga, Synthesis of Heterocyclic Compounds Using Carbon Disulfide and Their Products, J. Heterocycl. Chem., 1989, 26, 1167-1204.

10-G.S. Lingaraju, T.C. Vinayaka, K.S.H. Kumar, M.P. Sadashiva, K.S. Rangappa, An Easy Access to 4,5-Disubstituted Thiazoles via Base- Induced Click Reaction of Active Methylene Isocyanides with Methyl Dithiocarboxylates, Synthesis, 2012, 44, 1373-1379

11- Y. Tominaga, H. Okuda, S. Kohra, H. Mazume, Reaction of Enaminones with Carbon Disulfide: Synthesis of Heterocycles Using Enamino Dithiocarboxylates, J. Heterocycl. Chem., 1991, 28, 1245-1255.

12-Y. Tominaga, Y. Matsuoka, Y. Onlyama, Y.Uchimura, H. Komiya, M. Hirayama, S. Kohra, A. Hosomi, Polarized Ethylenes. IV* Synthesis of Polarized Ethylenes Using Thioamides and Methyl Dithiocarboxylates and Their Application to Syntheses of Pyrazoles, Pyrimidines, Pyrazolo[3,4d]pyrimidines and 5-aza[2.2.3]cyclazines, J. Heterocycl. Chem., 1990, 27, 647-660.

13-O.M. Singh, Dithiocarboxylates and Related Compounds in the Synthesis of Heterocycles, Book: Targets in Heterocyclic Systems. Edition: Jointly Published with Societa Chimica Italiana, Italy, 2012, 265-308.

14- E. S. H. El Ashry, A. A. Aly, M. R. Amer, M.R. Shah, S. W. Ng, Synthesis and X-Ray Analysis of Butyl and Glycosyl (2-arylamino-4,4-dimethyl-6-oxocyclohex-1ene)carbodithioates and Their Possible Cyclization to 2-Thioxo-6,7-dihydro-1Hbenzo[d][1,3]thiazine-5(2H)- one Derivatives, Carbohydr. Res., 2011, 346, 169-176. 
15-S-G. Zhang, C-G. Liang, W-H. Zhang, Recent Advances in Indazole-Containing Derivatives: Synthesis and Biological Perspectives, Molecules, 2018, 23, 2783-2823.

16-L.J. Scott, Niraparib: First global approval, Drugs, 2017, 77, 1029-1034.

17-R.S. baddman, N.U. Kumar, A.P. Reddy, R. Bandichhor, Regioselective methylation of indazole using methyl 2,2,2trichloromethylacetimidate, Tetrahedron, 2013, 54, 1661- 1663.

18-A.S. Al-Bogami, Mechanochemical synthesis of cyclohexanones and indazoles as potential agents, Res. Chem. Intermed., 2016, 42, 5457-5477.

19-M. Gopalakrishnan, J. Thanusu,

V. Kanagrajan, Design, synthesis, characterization and in vitro antimicrobial evaluation of 4,6-diaryl-4,5-dihydro-2phenyl-2H-indazol-3-ols, J. Enzy. Inhib. Med. Chem., 2009, 24, 480-486.

20-J.P- Villanueva, L. Y- Mulia, I. G- Sanchez, J. F.P-Espinosa, O.s- Artech, T. del R. SEspunes, M.A. Cerbon, K.R-Villar, A.K.R. Vicente, M.C. Gines, Z.C-Galvan, D.B. E. Castro, Synthesis and biological evaluation of $2 \mathrm{H}$ - indazole derivatives: towards antimicrobial and anti-inflammatory dual agents, Molecules, 2017, 22, 1864-1878.

21-Y. Wang, M. Yan, R. Ma, S. Ma, Synthesis and antibacterial activity of novel 4-bromo1H- indazole derivatives as FtsZ inhibitors, Arch. Pharm. Chem. Life Sci., 2015, 348, 266-274.

22-A. Chabukswar, B. Kuchekar, P. Lokhande, M. Tryambake, B. Pagare, V. Kadam, S. Jagdale, V. Chabukswar, Design, synthesis and evaluation of antibacterial activity of novel indazole derivatives, Curr. Bioactive Compd. 2013, 9, 263-269.

23-N.M.Y. Elsayed, D. A.Abou El Ella, R. A. T. Serya, M. F. Tolba, R. Shalaby, K. A.M. Abouzid, Design, synthesis and evaluation of indazole- pyrimidine-based derivatives as anticancer agents with anti-ngiogenic and antiproliferative activities, Med. Chem. Comm., 2016, 7, 881-899.

24-N.M.Y. Elsayed, R. A. T. Serya, M. F. Tolba, M. Ahmed, K. Barakat, D. A. Abou El Ella, K. A.M. Abouzid, Design, synthesis, biological evaluation and dynamics simulation of indazole derivatives with antiangiogenic and antiproliferative anticancer activity, Bioorg.Chem., 2018, 82, 340-359.
25-R. K. Bhatia, P. B. Raju, U. K. Jain, P. P. Kumar, K. Satyavathi, Synthesis and antiinflammatory activities of 7-benzylidene2,3-diphenyl-4,5,6,7-tetrahydro-2H-indazole derivatives, Res. J. Pharm. Biol. Chem. Sci., 2011, 2, 118-129.

26-J. Liu, X. Peng, Y. Dai, W. Zhang, S.Ren, J. Ai, M. Geng, Y. Li, Design, synthesis, and biological evaluation of novel inhibitors bearing an indazole scaffold, Org. Biomol. Chem., 2015, 13, 7643- 7654.

27- M. Yoo, M. Yoo, J. E. Kim, H. K. Lee, C. O. Lee, C. H. Park, K-Y. Jung, synthesis, and biological evaluation of indazole-4,7dione derivatives as novel BRD4 inhibitors, Arch. Pharm. Res., 2018, 41, 46-56.

28- E. Polo, J. Trilleras, J. Ramos, A. Galdamez, J. Quiroga, M. Gutierrez, Efficient MW-assisted synthesis, spectroscopic characterization, X-ray and antioxidant properties of indazole derivatives, Molecules, 2016, 21, 903-915.

29- E.S.H. El Ashry, L.F. Awad, M. Nabil, M. O. Kh, Bdeewy, A Novel Trans Amination Process in 3- Arylamino-5,5dimethylcyclohex-2-en-1-one with Nucleophiles and Antimicrobial Activities of Selected Products, Mediterr J. Chem., 2019, 7(6), 452-462.

30-I. H. El Azab, L.M. Break, Z. A. A. El-Zahrani, Synthesis-based heterocyclic compounds and study their biological activity, Orient. J. Chem., 2016, 32, 2435- 2449.

31- S. M. Ryadh, Enaminones as building blocks for the synthesis of substituted Pyrazoles with antitumor and antimicrobial activities, Molecules, 2011, 16, 1834-1853.

32- A-Z. A. Elassar, A. A. El Khair, Recent developments in the chemistry of Enaminones, Tetrahedron, 2003, 59, 8463- 8480.

33-E. S. H. El Ashry, M. R. Amer, A. A. Aly, M. Omer, O. M. Abdalla, A. A. Aly, S. Soomro, A. Jabeen, S.A. Halim, M. A. Mesaik, Z. Ul-Haq, Synthesis, biological evaluation and molecular docking studies of and benzyl, alkyl, glycosyl [2--(arylamino)4,4-dimethyl-6-oxo-cyclohex-1- potential immunomodulatory and immunesuppressive agents, Bioorg. Med. Chem., 2012, 20, 3000- 3008.

34- I. Jirkovsky, Studies on Enaminoketones, Can. J. Chem., 1974, 52, 55-65.

35- J. V. Greenhill, J. Hanaee, P.J. Steel, Some reactions of Enaminones with Isothiocyanates, J.Chem. Soc. Perkin Trans.1, 1990, 1869-1873. 